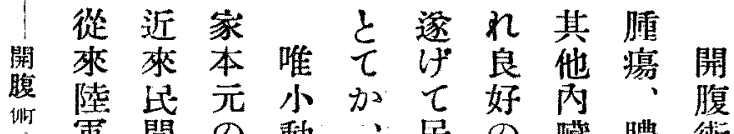

軍間の動。”居の歲膿術

般 獸 獸 獸物人方成 の瘍は

盤醫醫醫殊醫事績摘の腹

就學に $に$ に $に$ を出摘㓐

了校於於香比今納出內

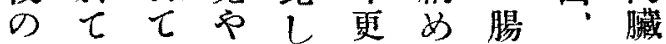

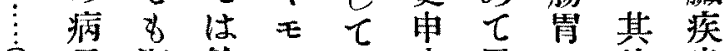

㝝馬漸餘儿比产 $の$ 他患

廠次 b E 較迄 b縫腸及

で此普 $\% に 反$ 合捻

每手及卜度あ殊、轉骨

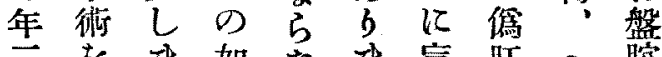

二老ま如なむ宣肚 一腔

‘行せき文腸門少

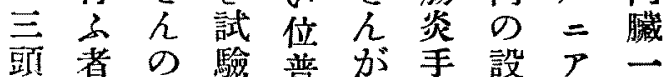

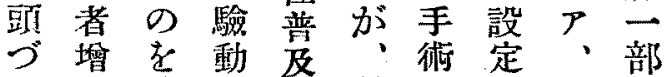

加遺物し翻 $の$ 等腸

$D D$ 揻 $\tau \tau \tau$ 如筑疾

隱傾之於居我令內頓患

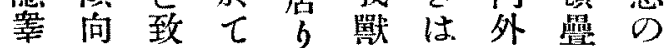

去にしは醫安科積時

勢 あま多这界全診等例

や b吉数んに療の人

明・加の於る整ば

巢誠實当名の調膀

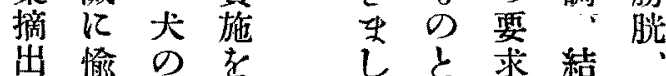

、快開自

稀 に腹る

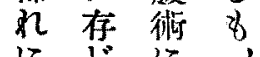

七纪石子

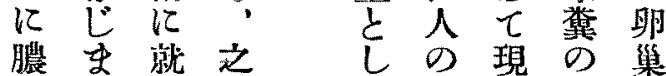

はて 基宫

開

礁

用

獸

腹 學
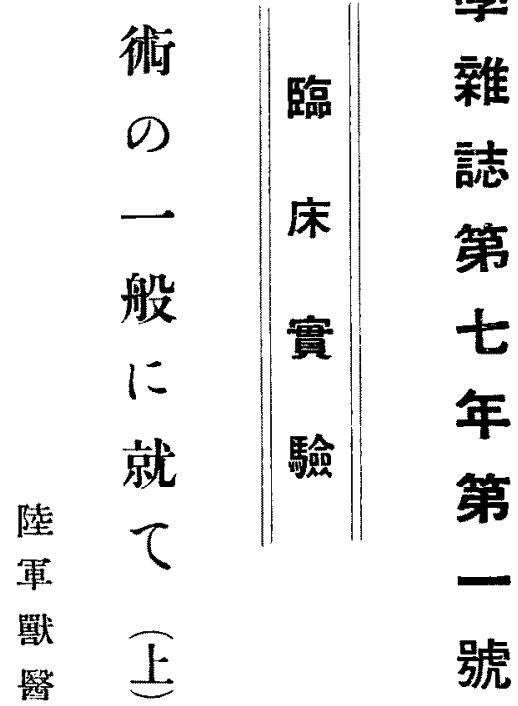

疼守 $\tau$ れ $\tau$ 信時除

等がはヌ經賴廣去孯

の、松多濟しく、缄

場 大葉

合 動 博

的七人 隐

關 疑 醫 等

に物士醫

係は界去

實 殊 等

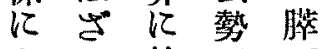

施 $に の$ 於

せ馬推 $\tau$

らに獎 行

ある於

万迄艺䛇旰次

れ就には物進術割脾

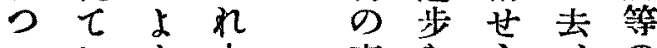

了は方本事老占合 


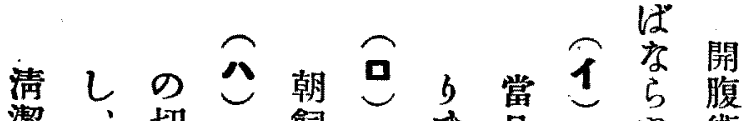

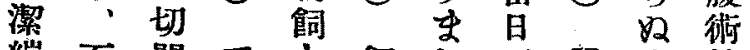
縦石開手と飼し'腸事前 帶簽を術共料て 早管はの 溫要前にはは朝の左準 施湯守日絕少: 石空の供 七でるに食く術龉慮諸は $\tau$ 洗 \& 開 女前水它點疾 置 天゙㇒の腹し क 數 々 渻で術め衡旦灌る 就す

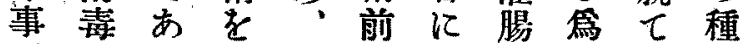
でし 3 施水三互をめで類 あたま方の日つ施手あ立 与刷しべみ頃てし術 $匚$ 手

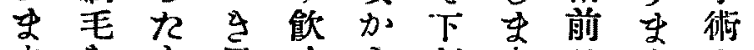

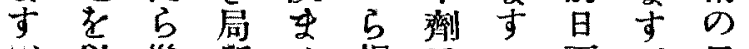

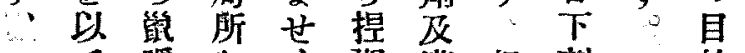

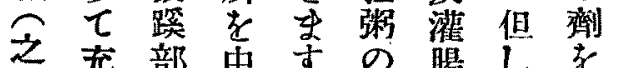

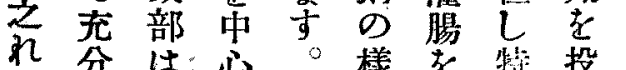
は分岕心禁学等投

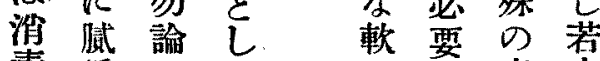

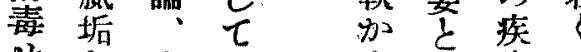

せを少店

总除痤了

局去股剔

所し毛

满消內 又

再毒面は

び綿 か 苟

污紗 5 毛

染 で陰 し

せ 充 露

12 分 殊

樣 涔陰

娍 拭 筒 第

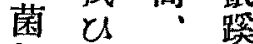

乙先臍遏

綿 部兒

紗九に尼

で 後 至 亞

包、るの

h出迄如

で來充了

置 得 分

くれ剃蹊

のば毛部
人守病は元

滋万で術自

養事あ前

性 80 万

のあて 灌

食b、腸

然老

興 守。行

手㐫の

術罴で

は 蓄 郎

流積 万

動的手

食九術

をし

取

5 居皎

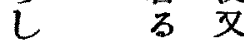

め者は

或で手

はあ衡
人。腸

多分。
九於故捻 あ

し

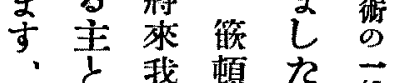

但亡我頓㤂盤

三二丙馬此公民憵

開腹践の術二間

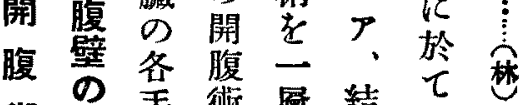

術局手術速屡結は

前所们就究等殆

$の$ 開就 咅練急占

準 导亲繁速 基

略し是開䆬

は噞し思 せ

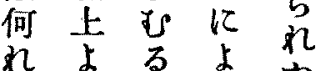

時 b ら

期必車

る 要救 哣

自, あは耷

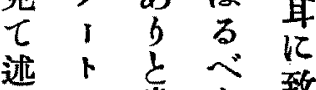

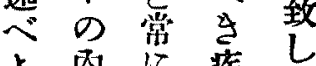

上 队

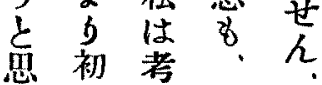

¿s 學 人 決 而

ま者てしし

守

䁷 5 尠牛

考 ま馬

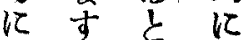

8 所云 は

文去

存 らな㐬 二

し・元の

以私惫外

下在は腸

摘 職れ 䍣

述忠安皘 
娄來があ溶腹腔

閏提沃揮 な膨 b 但液壁內開

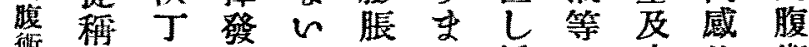
䜌の油かし世沃の皮染術

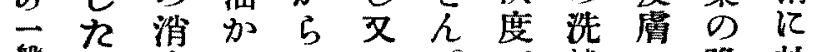
幋の毒及では。拭の豫於 就で力はす皮关䋖法消防七

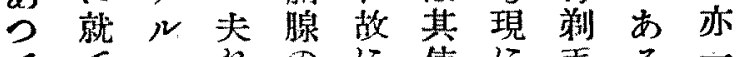

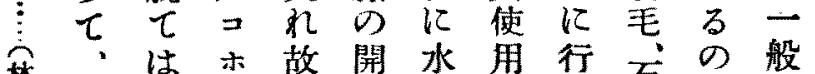
梦始今尔憼開水用行石の般 め更の若に洗吕れ险あ科 は审如し水っ適っ $r \mathfrak{b}$ 淮

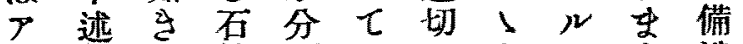
ルる高簽がすであコす寸消

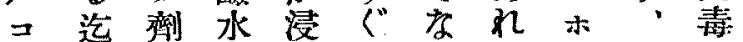
木反 ルながでしる扎名手法 一く、充てのば。”術式 ○普ゼ分居は充家ゾ中に 々に皮る禁分畜、に法 cc人含庴分物方にル特る にのむをらで效憵にの 對知世洗!蓑果角 注で しるて 紧沃、はすン意あ 沃所充し度な認る、吉つ 度で分て丁ぜめ最ル命て

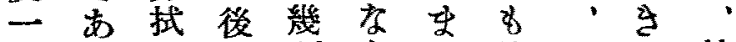
bつは古ら世簡名古絬 ○まれ善皮ばん單口の届 の守後々膚水有引老細 溶吕に乾飞洗第效 三 舉菌 液”沃拭深及一探ンぐ德 老此丁の々はにる丁れ染 用れを後進湯榦は."壮口

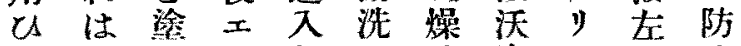
れグる、しのせ度バの止 の口老于て念る丁, 如節 でシ良ル充め面幾、く 主\%し、分皮に叙ルで化

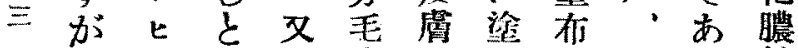
、氐致は穴濕ら法卜る性 近がし心迄潤孛でり。腹 比始むンのしけあバ膜

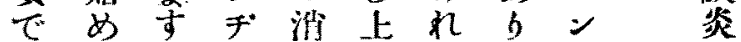

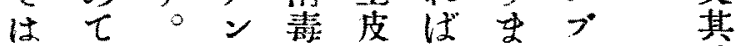
五此の㤎細效专 $\%$ 样出胞吕。户腹

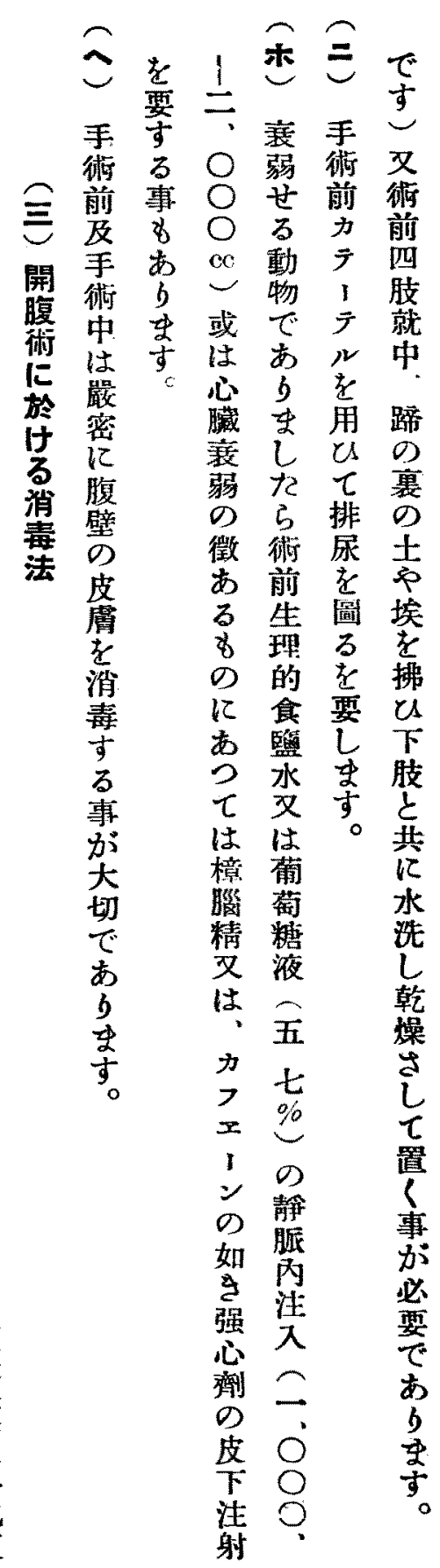




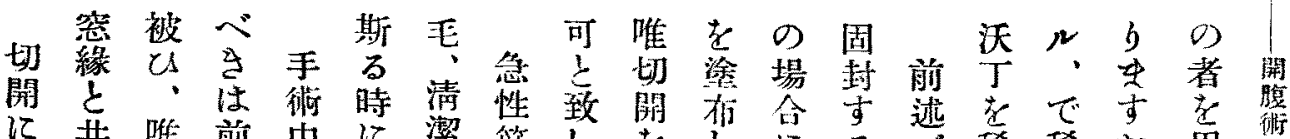

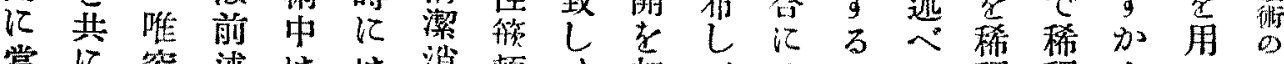

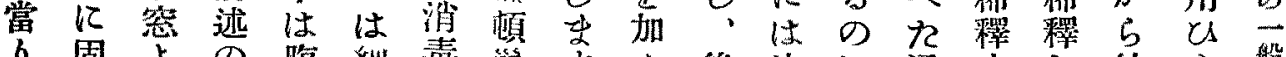

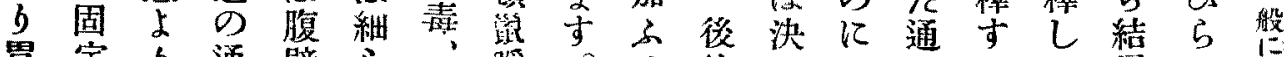

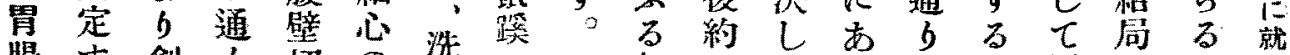
腸す 刢 $b$ 切 のる 面。開注涤，

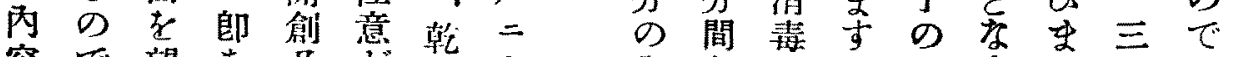

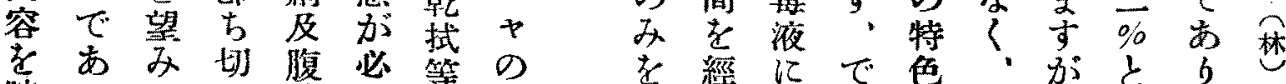
貯る 得 開腹 要等

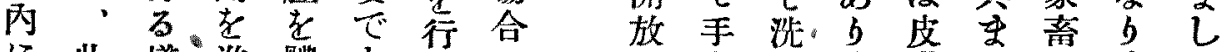

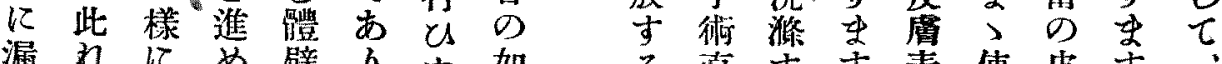

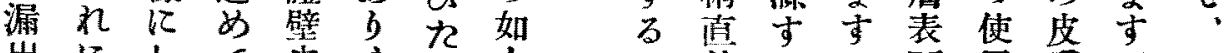

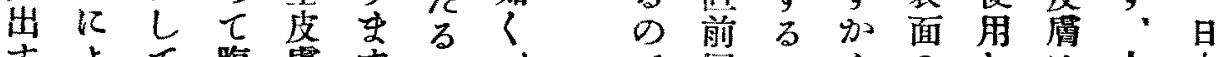

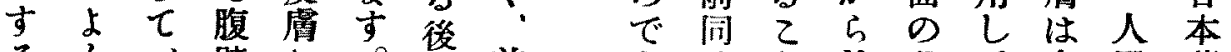

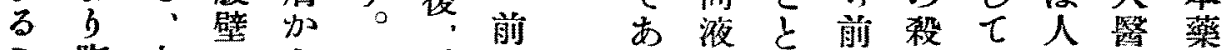
之腹皮にら二云

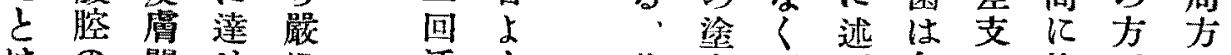
はの 開世沃 最內鈎し遮度の貝圭全た論なしは沃

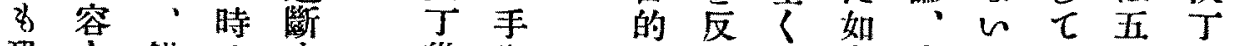

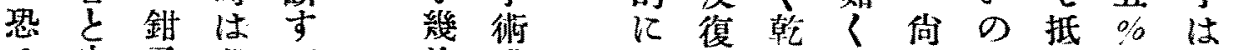

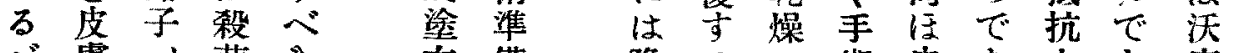

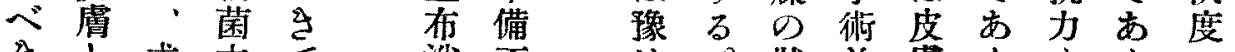

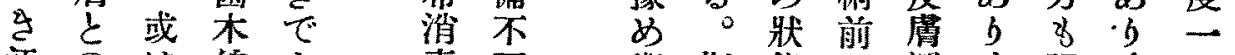
污のは綿あ 毒可 畐斯態日㳭ま强ま 染接腹若る 法能野々皆大部主し方。

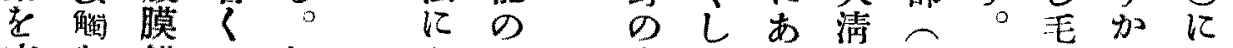

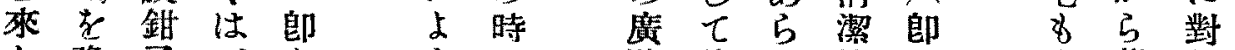
た 豫子ガ

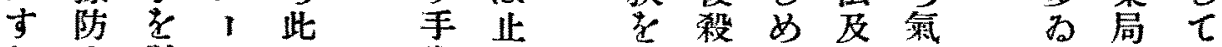

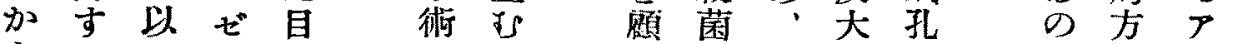

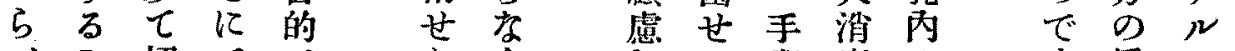

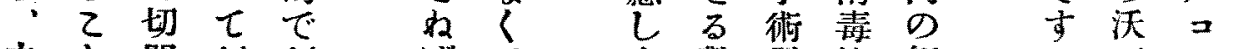

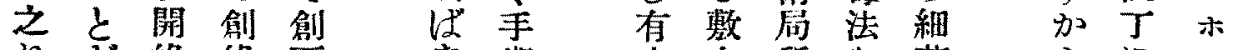

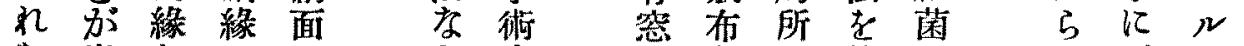

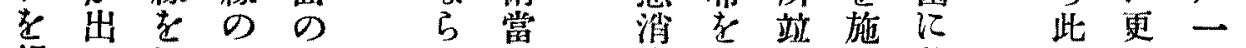

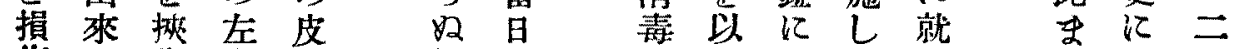

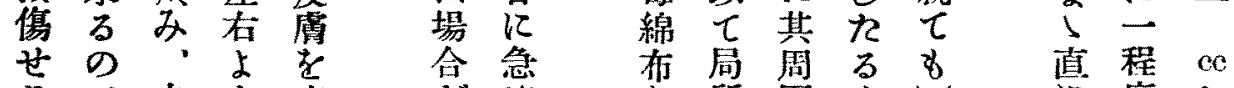

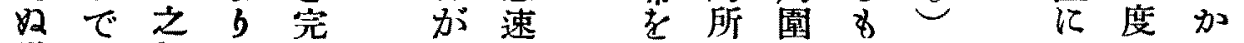

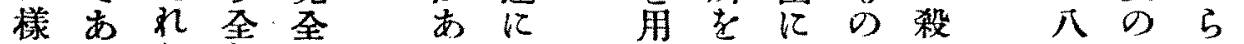

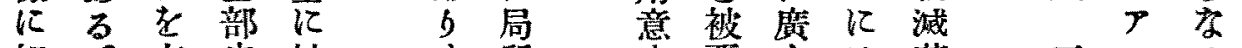

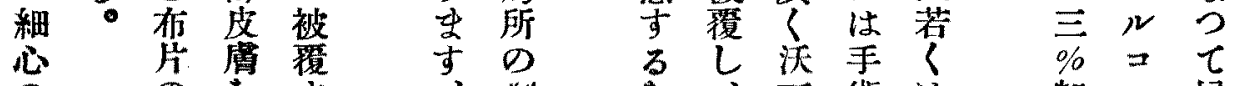

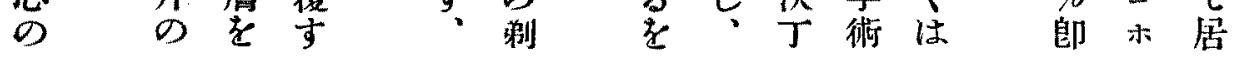




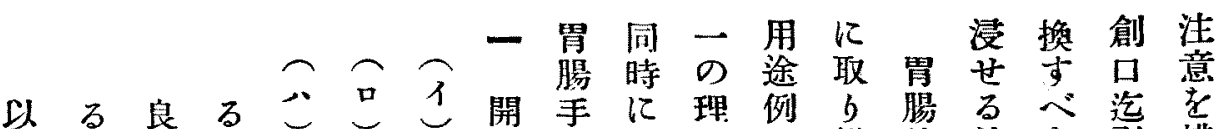

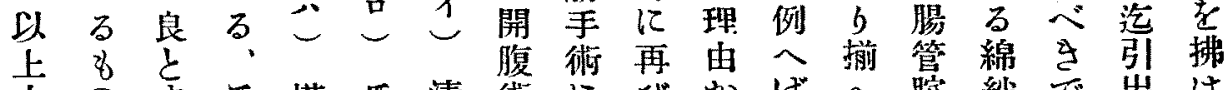

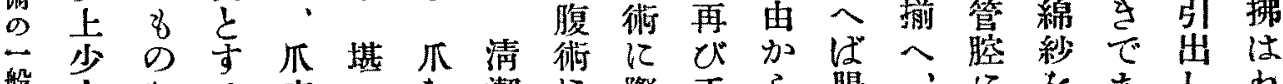

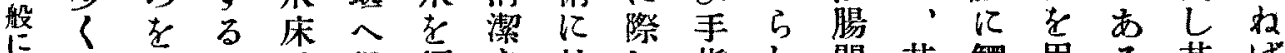
就引引、及得短な於し指し間基觸用当、其代

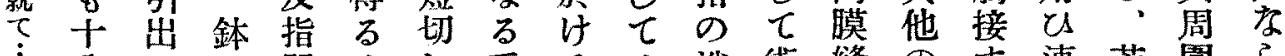
分し市間文し手るは消術縫の方速若園ら

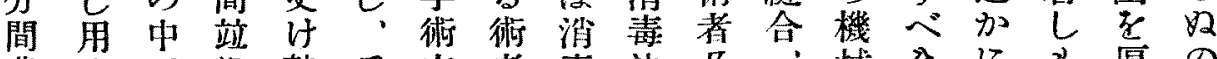
㷊費ゆでに熱爪衣者毒法及峨される 厚の 寸

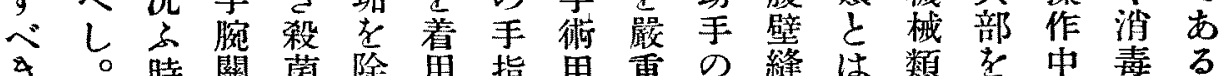
時關菌除用指用重の縫は類掝中毒る

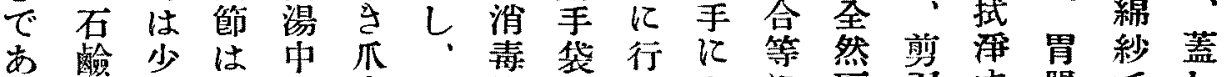

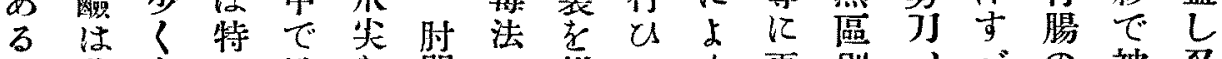

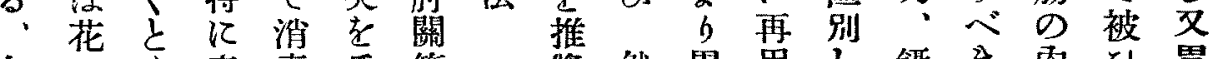

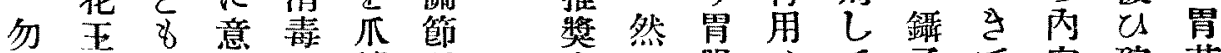

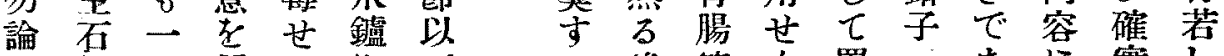

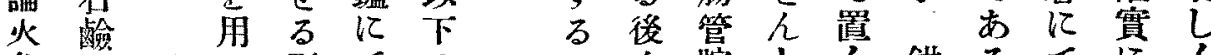

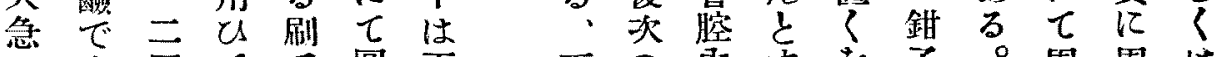
の宜回て毛圓兩而の局方子。周周は 場しは充と滑侧し操容る必園圍腸

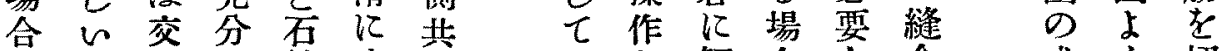

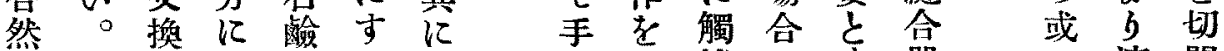

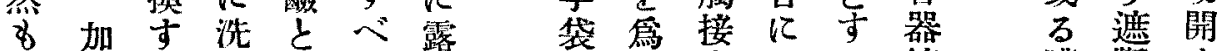

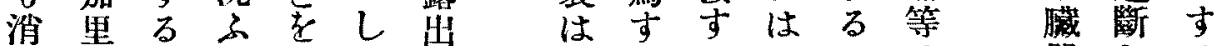
毒石のべ以宁隨べべ:、は器しる

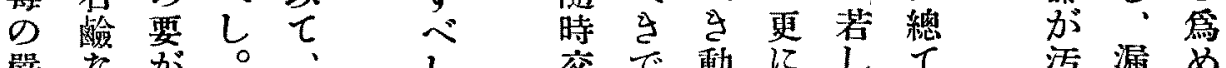

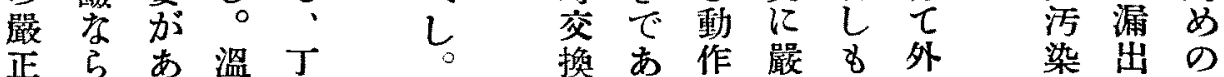
を佔る湯寧艺る密二科せ物手 餘姫、はに

马可刷 流 殘 にな毛下る

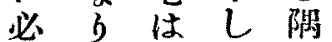
要で一つな ぜる 消あ 前 る。毒る膊 場 L 菌手 例水角指 $\widehat{0}$ 中 3 药 ば にる清

開浸范沿 腹せ最す

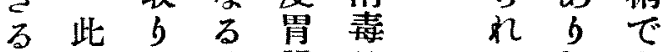
加不九消腸的九しあ ら便る毒內法る 時つ でを場を膃則時はて あ除合行とに直な るかには觸依は方 。んは、权接 $b$ 殺にば 品: ばし消菌新 雼其な毒生ら成 め處 3 る 我置专可方的导

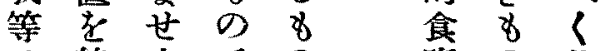
は終んでの 監の此 特る。他を水とれ

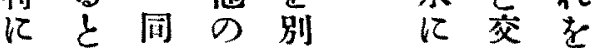




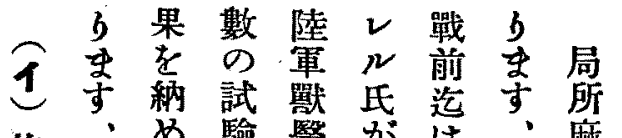

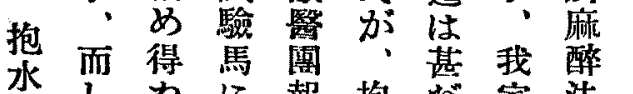

水し た

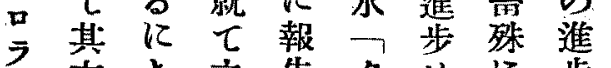

方よ之告夕せ步

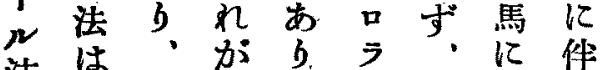

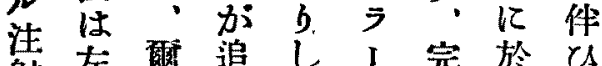

射左爾追試劣完於 ひ

液通我占以し全ま歲

㹈 6 品共七 の麻し手

法で陸に”静醉て 衡

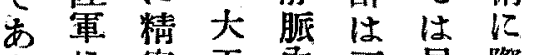

bに密正內不局際

於尔千注可所

は實年にの醉名

開 驗 以 就 者は全

腹と降乙主略身

術研我多考医麻

の究台數へ人醉

場と陸軍ら贀の

合軍馬界雔

に重獸に元用

は䙞試居同は

絕 其學み

對最校・少に次

的 \& 病 新 $\mathrm{L}$ 其 制

必安馬九た目限

要全㖪な! 的せ

なににる所をら

万し於方加造れ

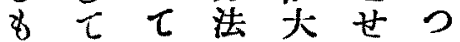

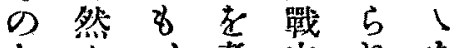

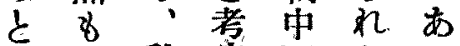

し確私案獨九る

て貝はし逸るは

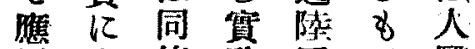

用完僚驗軍、醫

せ全との 獸 全界

ら に共結醫身の

れ麻に果官麻 現

つ醉當を力醉狀

〉口時獨么はで

あ效多逸 メ大あ

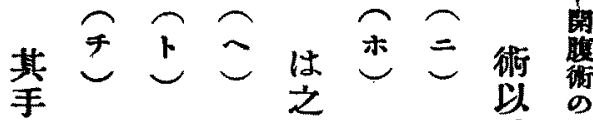

で手消其れ普䄶外

煙術毒後は通菌の盤

四草に世千略 $ア$ 乾手就

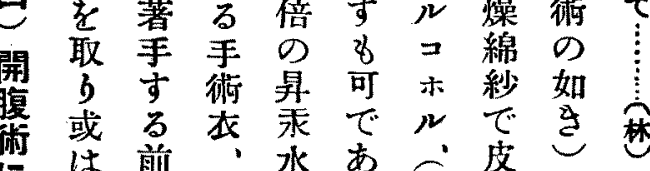

には前帧水ある方秡時

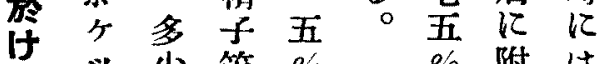

るッ少等 $\%$ 学著隨

柘時着义 中時

法手間角1 13 其

浸 水 時

万艺水分間

れ場双 る壱

万合は綿弑短

等に

禁消监等

物 毒 ゾ 三

でせ 1 分差

ある間支

る 手 水 許

は年手饩

消刷指

毒毛章

紗员方

に $\tau$ t

$\tau$ 三 法

被首京

七 分 万

置閻名。 


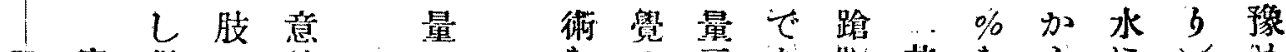
開 惯 得 $の$ 的 $-\overrightarrow{0}$ c 支

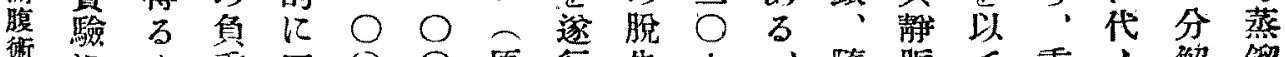

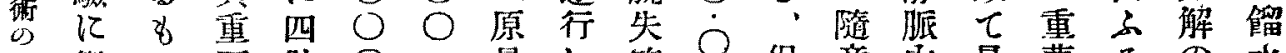
船 徵 $の$ 不肢 $\bigcirc$ 量 $L$ 等 般すで磪索

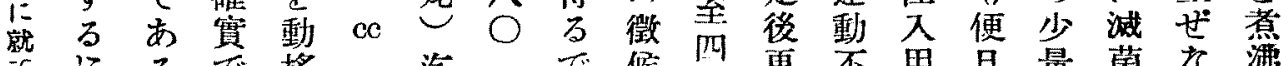

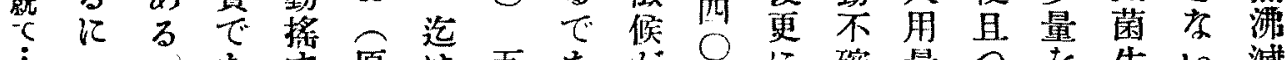

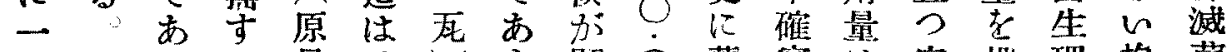
$\vdots$ 時 つ 万 量 時 $ら$ 顯 $\bigcirc$ 藥貿は安投理抱菌 㝝間て五間以ふは死液と體全し 的水し

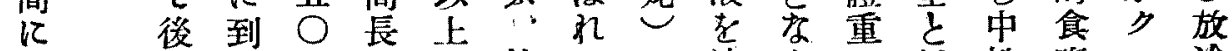
涉躲 b

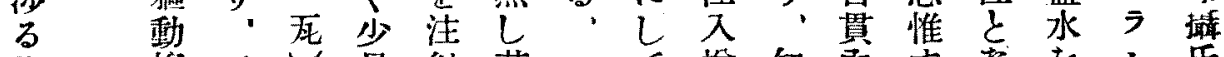

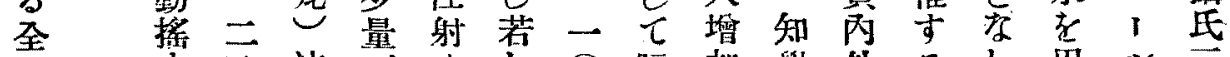

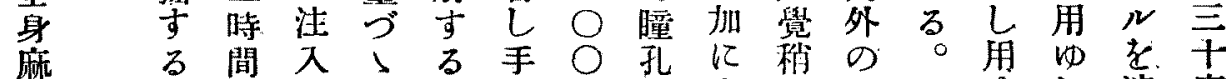

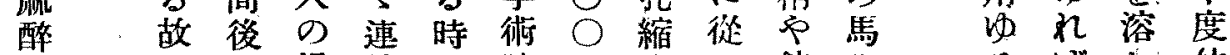

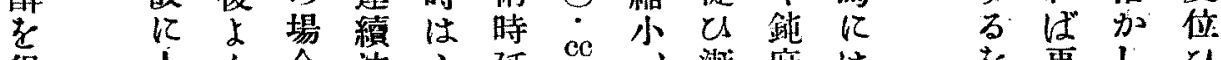

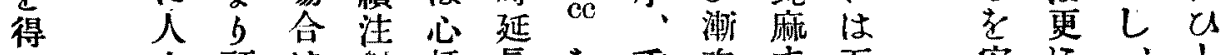

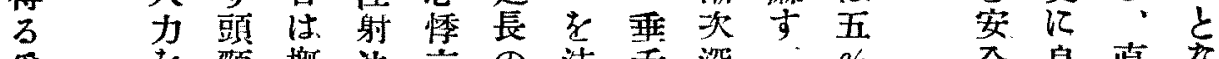

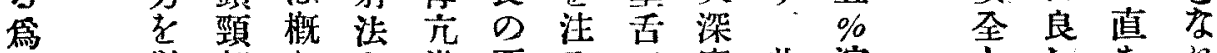

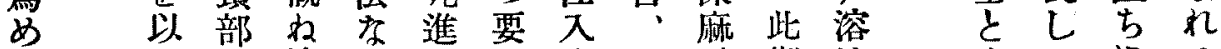

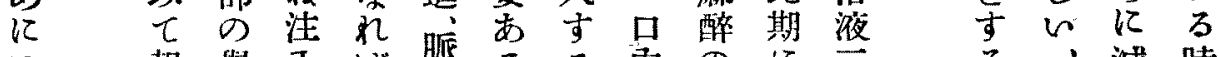

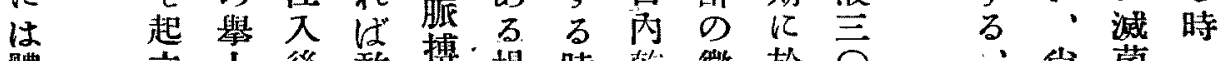
體 立 上 後 敢 疾 場 時 蜼 徵 於 $\bar{O} \cdots$ 们 菌

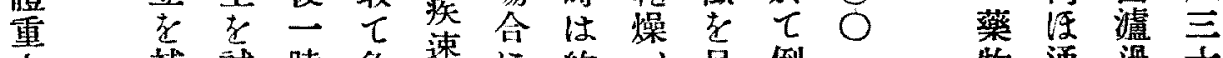
干補試時伦速に絽: 呈倒物通過十

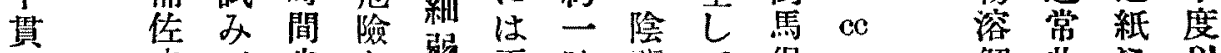

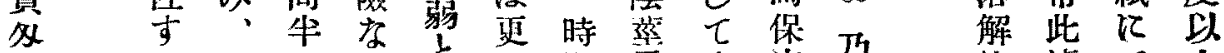
にる

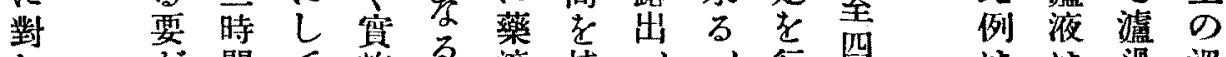
乙 が間て 施 る 液 持 抱 水 る ク、立に方古注る結分は ce 五》直抱

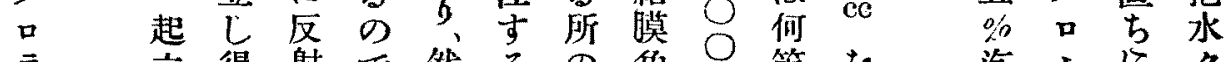
ラ 立得 射で然るの解等をを迄、に

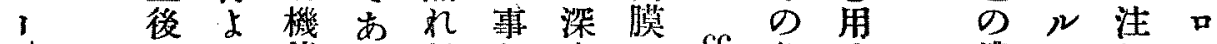

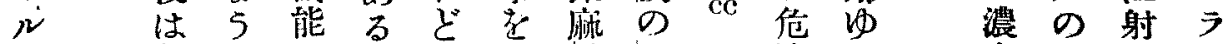

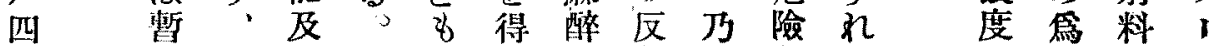
七 時然知二るを射至 な ば

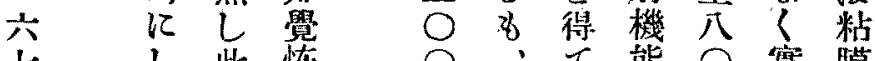

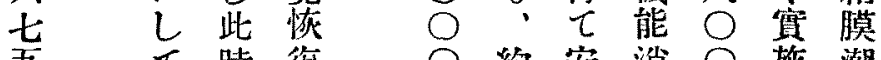
死七時復 $\bigcirc$ 䄪安消 $\bigcirc$ 施潮 郎自に c c 六全失 co 得紅

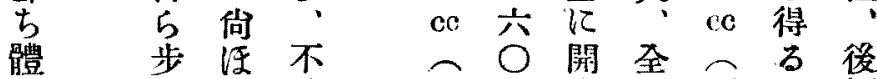
重行四随原 $\bigcirc$ 腹知原の 軀 虽弱守分 重酸 る。解 8 性 繁学吉恐 然寺 蒸れ 五る餾あ 


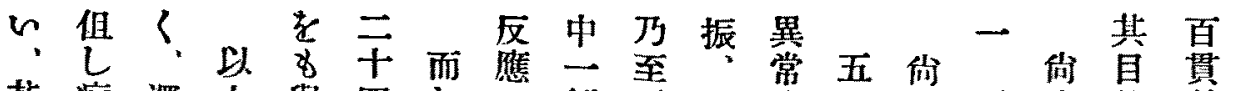
基 病 深上與四し の 例三腸 8 \% ほ 石全的 以

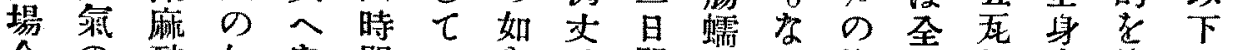

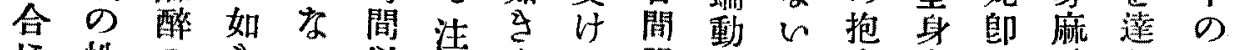

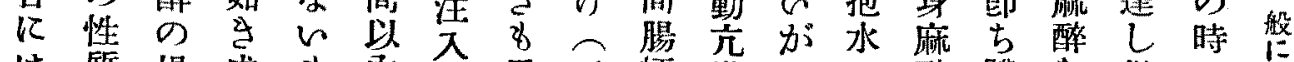

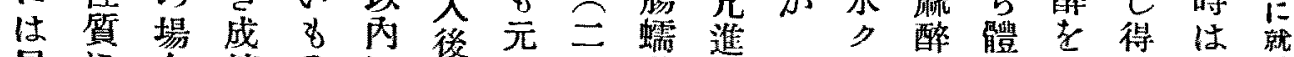

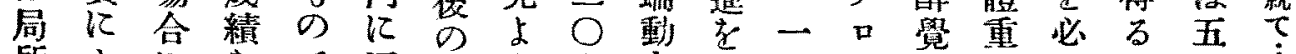

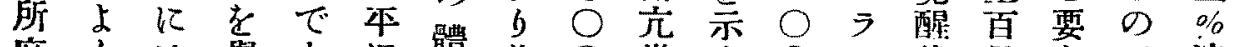

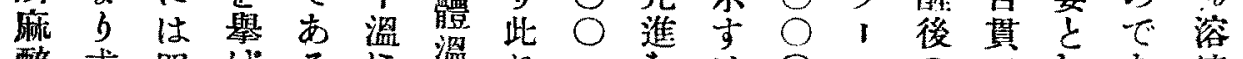

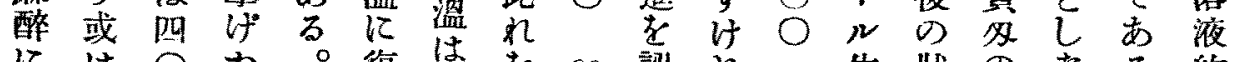

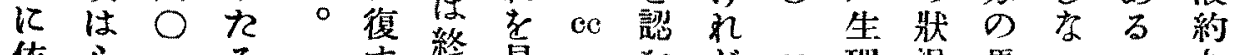

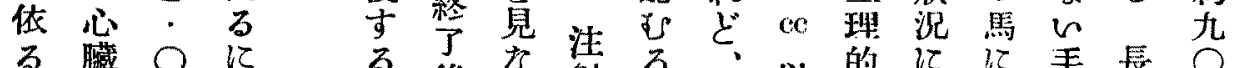

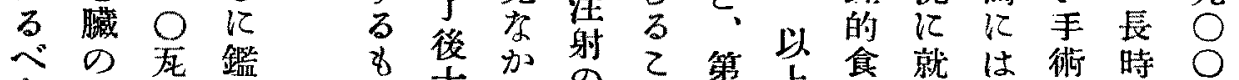

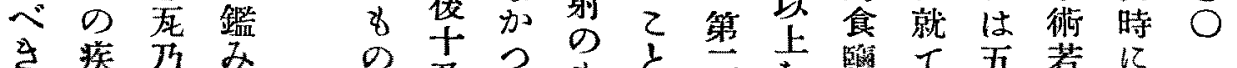

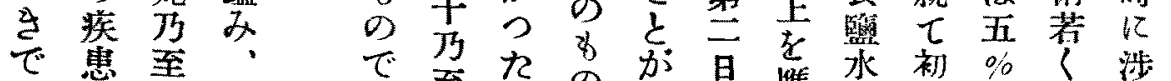

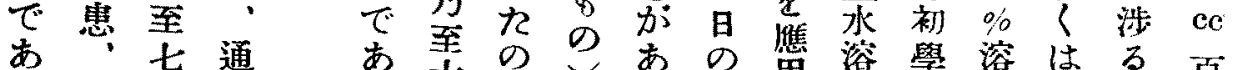

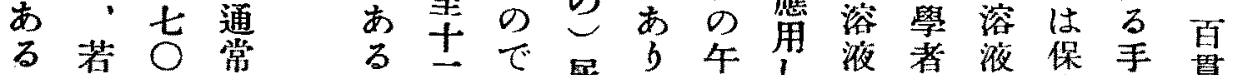
人 牛

は○麻

裹死 醉

弱に に

あては

る充抱

分 水

の

其

就自 5

$\tau$ 的 $I$

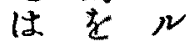

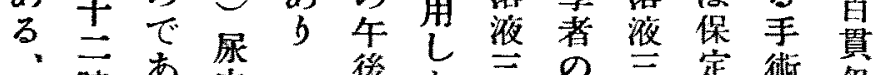

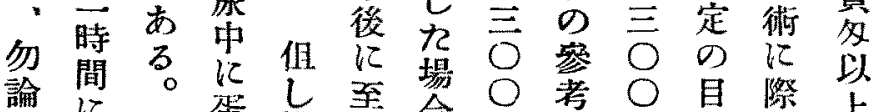

全逵五

期得

醉 万○

の 2 再

禁文号

忌 d 至

势 思

$\sim$ U 0

事尔

は。死

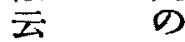

及 注

स 射

で で

な 严

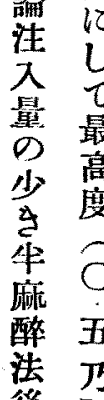

後 至

如 -

घ 0

堨 新

合通

に 0

骨霎 五

體五

ic D

\& म

何

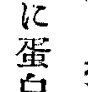

非合

粪

䋢

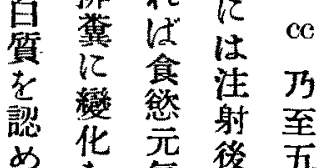

め化元後五

が呈蜞 第 0

其当年 $\mathrm{cc}$

他迄古前

多は霄渠注

數至䈏造

は至它通 入

此劣る、虽 る

的光。動 8

認大併物市に

め大量時 䒕は

学洼と時姚何

$\supset$ 射亡稍等

隻元沈特

考 0 目 祭 上

な cc 郎七 旦

る の占位市

墨 入 磨 後 貟

の に酷其迄

はよ目桨は

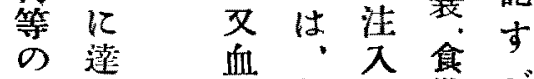

影 ᄂ

血数 後欲 今゙

莱例些不文

$\begin{array}{llll}\text { b } & \text { 目 } & \text { 沉 } \\ \text { 其 } & \text { 的 } & \text { 約 }\end{array}$

其 に 憵

貝的岕

䇺 追

達 旦注 $\mathrm{cc}$

方賈射 乃

軎: 多表至

䓵對方 二

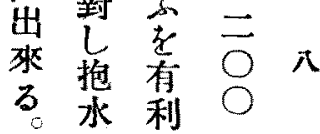

> 致 $\mathrm{cc}$

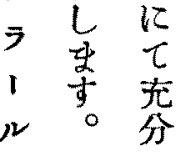




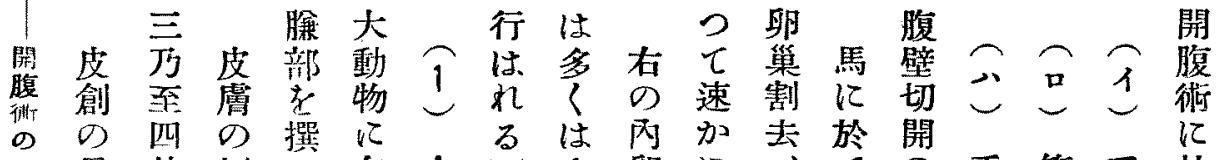

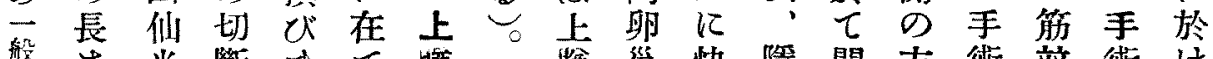

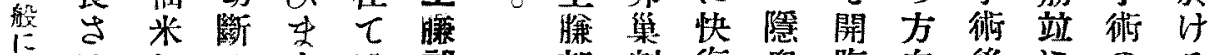

就は分は卞は部部制復等腹向挠にのる

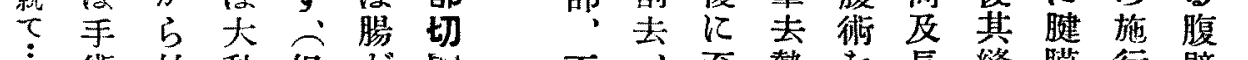

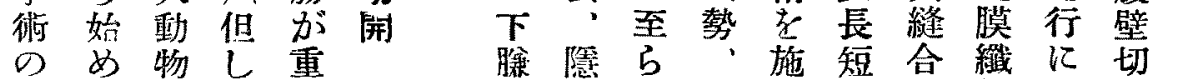

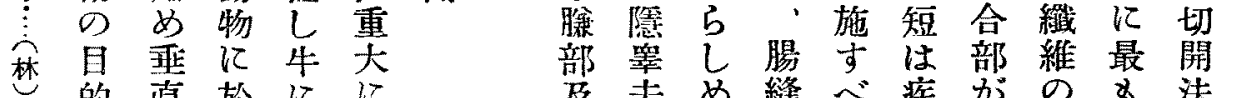

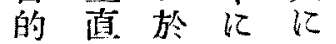

飞放し

從下はてて

方腸は創

七 骨第口

多延外一よ

少長角胃 b

のすのの 脫

差る中手出

は, 央術し

あ此上口易

万際 万時 豆

加旋季の故

一通 肋外上

五腹骨は脸

乃動部在部

至脈江堔で

三 の水部手

○枝平老術

仙はに撰亦

米自引ぶ

然 叉活

澾切京

专 斷 万安

るせ線全

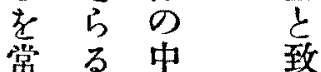

主苔部主

九量常で、吉

守腰馬

及去め縫 ベ疾がの8 法

腹窪九合さ病最橫便撰

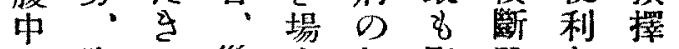

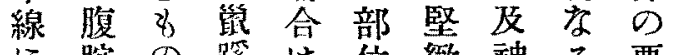

に胫の蹊は位緻神る要

於膘でへ帝及に經部點

て㾇あ几王手しの位は

腹

開、る二手術て切を右:

壁

切

開

法

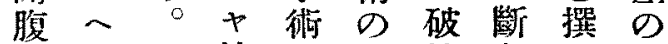

せ $ル$ 等自綻を艺如

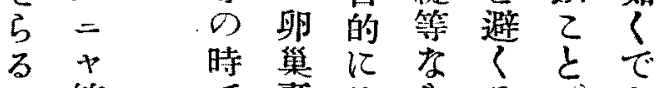

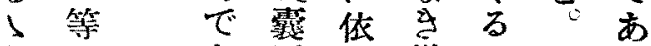

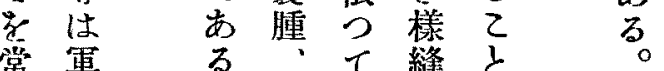

常軍馬子交縫京

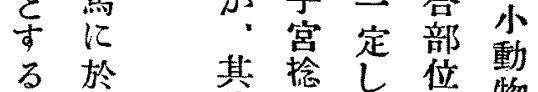

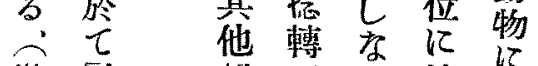

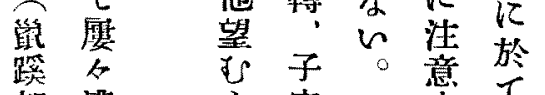

部遭富守守

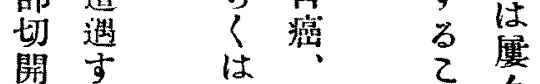

はる 特腹主橫

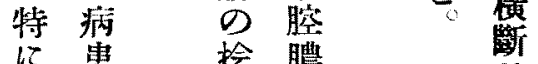

患捻膿的

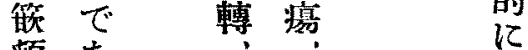

頓古重腸切

篦? 重腸結斷

る椎㴖於

等於

起壮

下左

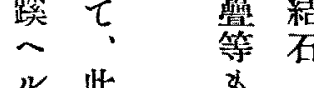

g

二紫此骨

$+i$

手 盤

の 對 術 膿

際し に

3
贷
險
な
し 
腹る部の開と過にら切 郎出方垈哆加報敏入はる開 方桃法白心開一告性心我べは 仰万を線儿す潘世を艺名马白 卧か取にドる宜ら比ンは線 保 52 立立二樣乙化較

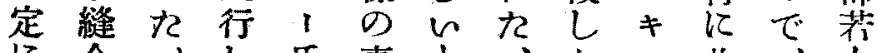

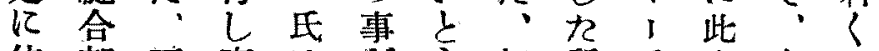
依部而直は名主即所氏術大は 了はし腹單な張ち古は式動此

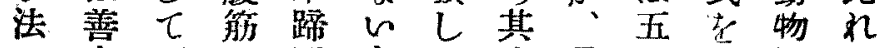
の\}下の獸と, 成最十取にに

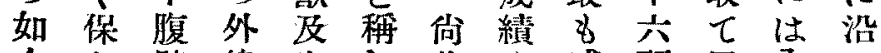
〈 壁線牛 $L$ 此 \& 感頭居內 消れ切飞《立部亦染の方臟て 毒、開沿於居 は緬し動方脫行

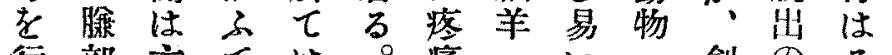
行部主卧痛的邻のる

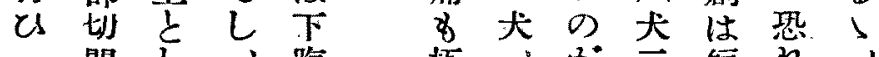
先式 $\tau$ 牝壁 づ よ 腱 獸 の 皮方質衹白 膚8 部於線 安 $\tau \tau$ 附 腱全於は近 膜 でて 乳 の あし、居切

白方、の開 線亡直基吉

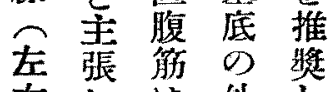
右しは外 し 直 $\tau$ 唯 侧 $\tau$ 腹居符江居

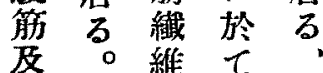
横 の前 及

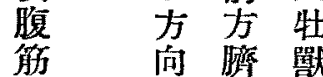
の $\quad$ 制 睷 分緣於

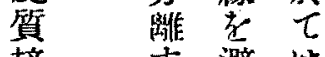
接过避 合方诂包 線头 $\tau$ 皮

计切 $D$

横で開基 筋

\section{極: 加三短れ。}

め猫馬士㤎出 てで頭故あ!

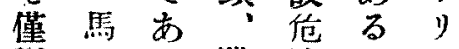

徽口猫险加

飞㮌て八少ら 古序頭加用改 つで最: b的栤 て市名馬しざ

然亏鈍十反方多 为性頭口农农

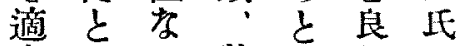
度のの牡証しに 牙事汼め依 太芯緬士九教往

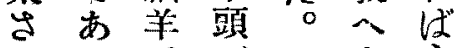

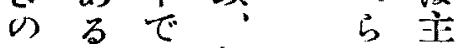
絹、緬风衣

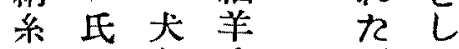
では公少的 階风猫頭吡 段各的䃑式

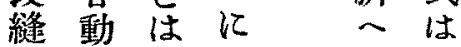
合物此就少小 共中几二動 主白間腹中物 れで線等纪 代部亦威の適 㓱口染場用 緑切九因せ
內, 切 (3に名皮 2 開 走少 2 腹 和代 腹るに大下 中 1 : 從動 的般 線㙏公物部就 切動ばに切 て 開脈膝 於開 蓋て 稘滑は つ腸 〈上骨 万線 解 之. 加 の と 5 下 が助 方 あ 趣 約 る管一 加撑 ら可幅 豫加の め百 所 注、少 意水 ら 本 始 要線 め 万於 斜 七 切 $に$ 皮寺 乞 方 L ל 5 敎 前 人下 b 斿 隹 72 及 此 D 場 で 合あ Ko 腹七 笪 水 
際豫 あてする離更先 たの\&術左又膜 閶的め腹る 摘

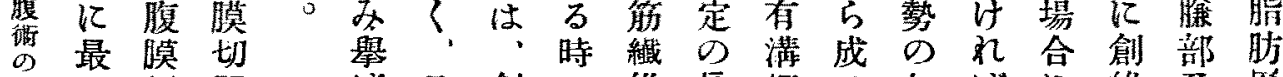

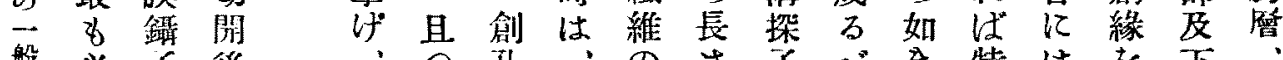

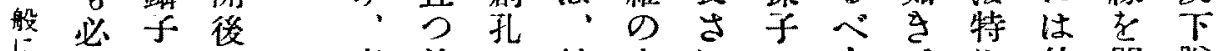
就要支は直前に茹方にのく場に外開脸腹

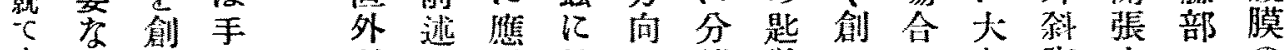

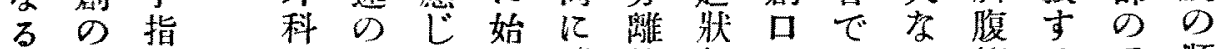
要上学入防て文问終部のは方觔る 手順

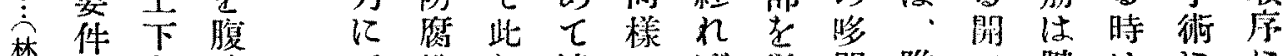

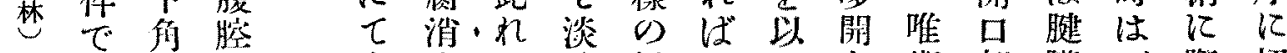

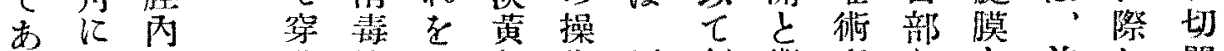
万抵江法切出作更㓱術者艺亡前し 開

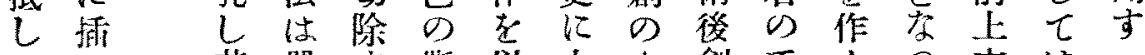

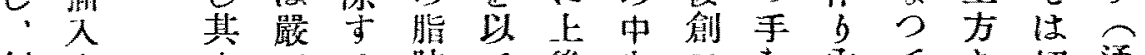

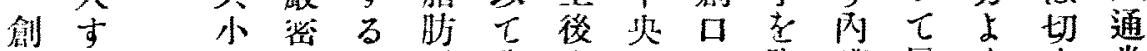

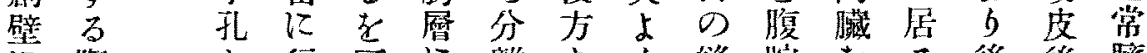

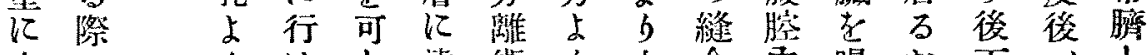

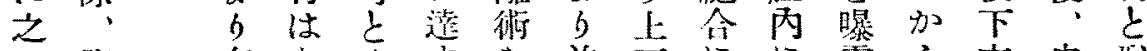

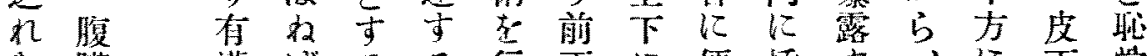

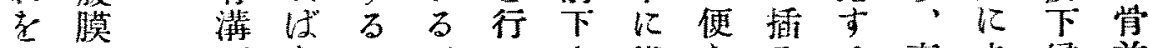

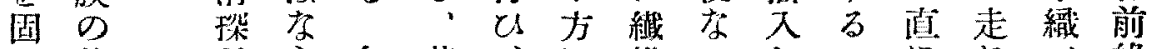

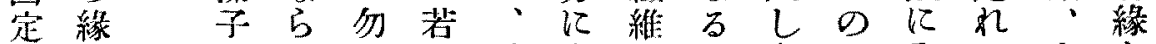

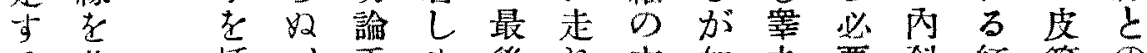

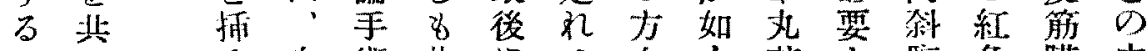

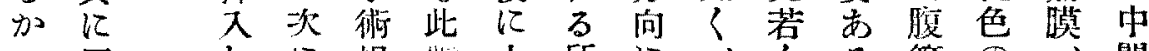

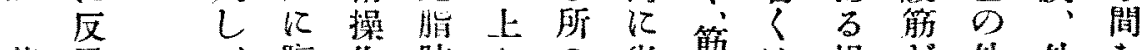

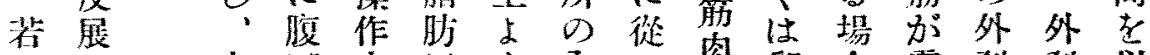

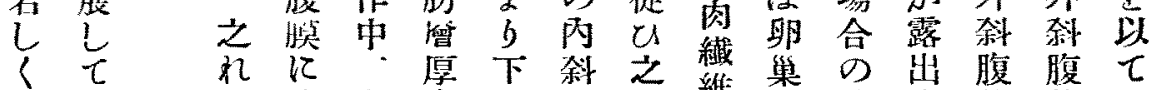

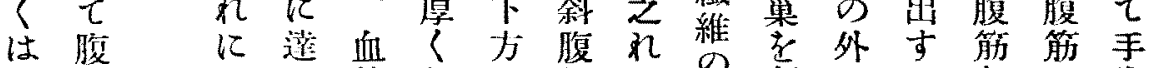

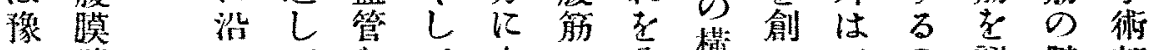

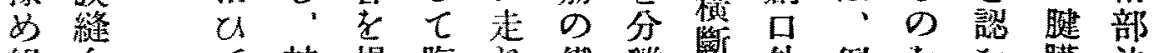

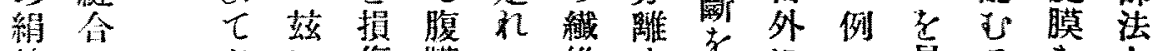

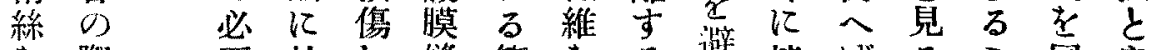

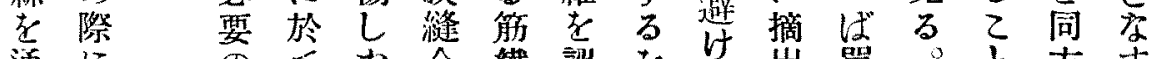

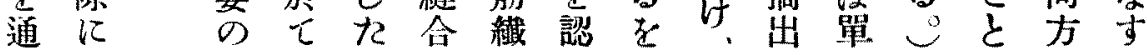
乙困 長腹場の 維生良外手汇此加向。

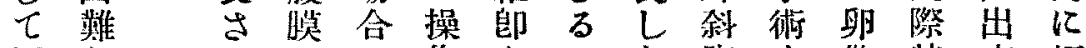

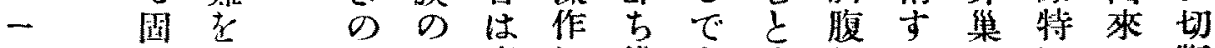
定来切一直 亿满 あ

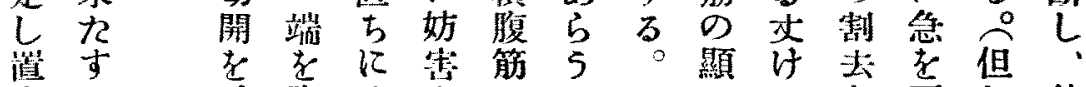
$\zeta 2$ 試 嗄止古の

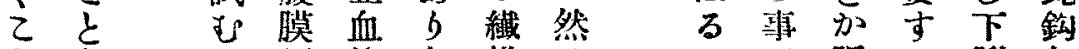

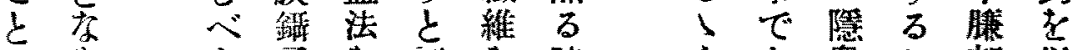

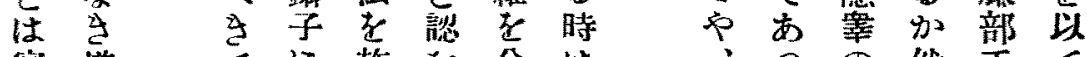

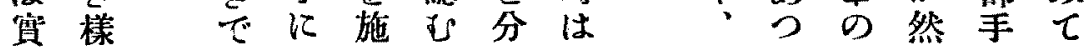




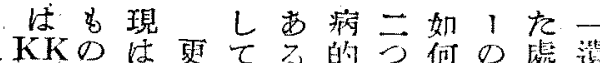

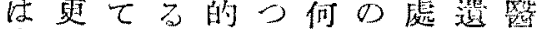

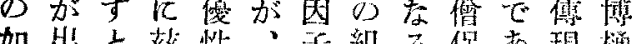

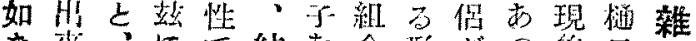

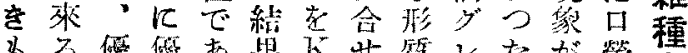

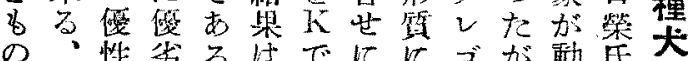
の、性少るはでににゴが動氏 師的遗のか病あよて、相はの

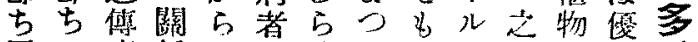
同一病係で之はて落索生趾 質はに死あ存す存し邓學學症

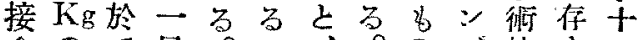
合のて目口の门合そデ的す— 體如はにでKG今れルにる月 でを因見あは健が比創て跟 西異質る る牛康遗で設とに る質型焉。分因倡あしは於

。接をにそ焺子性るた古て 合異之狆け老可人來的

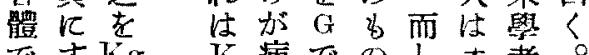
です $\mathrm{Kg}$ K 病でのし才者 あるの が的現でて、の

り 吉田因仕あ人下注

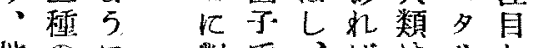

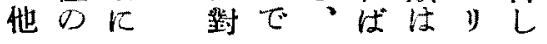

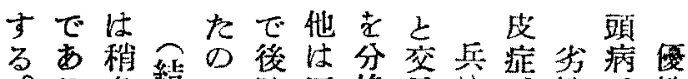

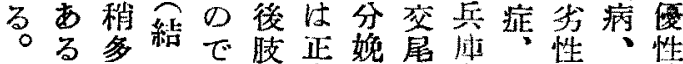
如く論あ恃常LL楮先遗裂遗 く学方右でたて川关傅足傐

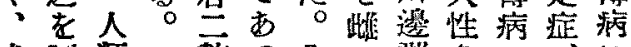
犬認類整つ之三郡魚に、に にむの趾たの頭川解は先は

於石整:。内西症先无短

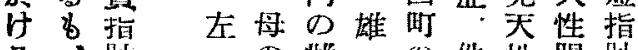

万、趾 $\div$ 雌二D你性眼趾

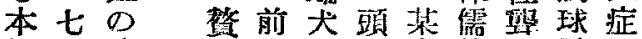

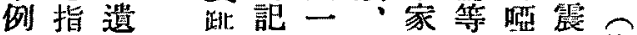

は七傳及雜頭鹤のが症湦指

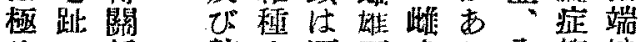

め係整犬两不犬方全等缺

て䀵索趾を後明へ。身が損

稀形見痕檢䀧の䆶性あ症

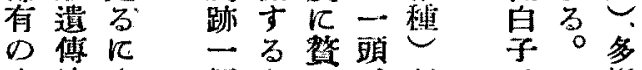

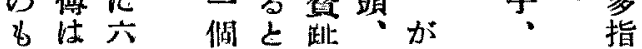

白の秘指を前を都不色趾

䔝惫元交岳肢認合明素症

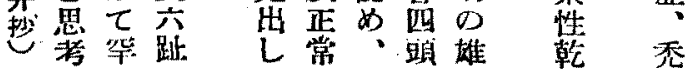

踰簤林跕

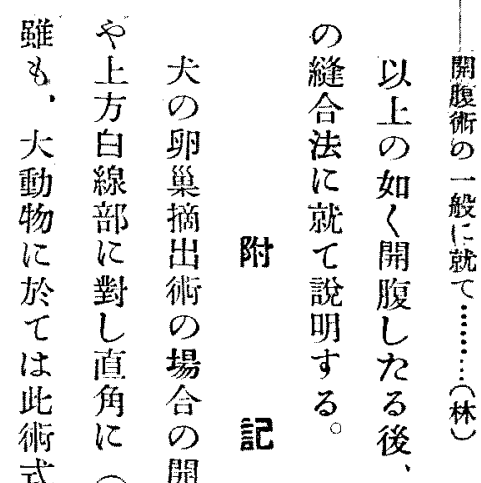

は所腹

取 謂 徯

府

5 瀵 に

尔覓 就

几

膜は

汽松

切葉

掝

寸士

る 及

の 其

方 他

法同

老 你

取 諸

与 氏

結 の

果 現

極 に

女 行

$\tau$ Us

良つ

好

な あ

るる

法

筫 式

驗は

○ 乙 䐮

下 部

次

臟

D

手

㭪可

に

移

万

の

で

क

万

加

此

虎

k

は

蹋

K

開

腹

衔

文

け

D

說

明

に =

等

め)

次

K

腹 b

㓣 